Article

\title{
A Prelimary Molecular Approach for Characterizing Microorganisms Having the Potentials for Bioleaching of Iron Ore
}

\author{
Emmanuel Ekpa ${ }^{1, *}$, Ikechukwu Onwurah ${ }^{2}$, Lawrence Ezeanyika ${ }^{2}$, John Odiba $^{1}$ \\ 1 Department of Biosciences, College of Natural and Applied Sciences, Salem University Lokoja, Lokoja, Nigeria; \\ Odibajohn@yahoo.com \\ 2 Department of Biochemistry, Faculty of Biological Sciences, University of Nigeria, Nsukka 410001, Nsukka; \\ ikechukwu.onwurah@unn.edu.ng (I.O.); Ezeanyika.lawrence@unn.edu.ng (L.E.) \\ * Correspondence: emmeks@yahoo.co.uk; Tel.: +234-703-613-5834
}

\begin{abstract}
One consequence of the global technological advancement in conventional metallurgy is the fast depletion rate of valuable minerals, which are also becoming increasingly difficult to find in pure and economically viable forms. This has spurred more interest in technologies that investigate ability of different microorganisms to mobilize valuable metals from their ores via diverse metabolic processes. This study was carried out therefore to isolate, identify and characterize iron solubilizing bacteria from Iron stones of Agbaja iron ore mining site of Kogi State, Nigeria. Crushed samples in the range of $0.25 \mu \mathrm{m}$ and $0.75 \mu \mathrm{m}$ particle sizes were cultured in a modified 9k media to facilitate bacterial growth and pure cultures were then isolated and sub-cultured for further bioleaching studies. Morphological and biochemical analysis suggests that some of the bacteria identified are members of Acidithiobacillus spp, Pseudomonas spp, and Leptospirillum spp. Studies conducted on pure cultures and mixed consortium of the identified organisms shows that a mixture of the three organisms leached iron ore to about $96.16 \%$. Also results of growth pattern due to bacteria countafter 24-72hours of incubation ranged between $0.1 \times 10^{3}$ $\mathrm{cfu} / \mathrm{ml}$ and $12.3 \times 10^{3} \mathrm{cfu} / \mathrm{ml}$ for Acidithiobacillus spp. The need to explore the molecular characteristics of these organisms with a view to generating more information on the quality/quantity of their DNA for future cloning activities was also investigated in this work. DNA was extracted using zymo fungal/bacterial extraction mini prep kit ${ }^{\mathrm{TM}}$ (cat \#6001) and subsequently subjected to $1 \%$ agarose gel electrophoresis. Visible bands were obtained with Alpha Innotech Gel Documentation Machine. DNA amplification was carried out using a pettier based thermo cycler PCR machine and electrophoresed on 1.5\% agarose gel. Results of the PCR shows a visible band corresponding to $1.5 \mathrm{kbp}$ using this primer $27 \mathrm{~F}\left(5^{1}\right.$ GAGTTTGATCCTGGCTCAG-3 $\left.{ }^{1}\right)$ and 1492R ( $\left(5^{1-G G T T A C C T T G T T A C G A C T-3 ~}{ }^{1}\right)$. DNA purity check shows two of the bacteria possess very good qualities for sequencing for further molecular analysis.
\end{abstract}

Keywords: bioleaching; molecuar analysis; bacteria; sequencing; iron ore 


\section{Introduction}

Iron ores are rocks and minerals from which metallic iron can be economically extracted. The ores are usually rich in iron oxide with other accessory gangue phases and vary in colour from dark grey, bright yellow, deep purple, to rusty red. The iron itself is usually found in the form of magnetite $\left(\mathrm{Fe}_{3} \mathrm{O}_{4}, 72.4 \% \mathrm{Fe}\right)$, hematite $\left(\mathrm{Fe}_{2} \mathrm{O}_{3}, 69.9 \% \mathrm{Fe}\right)$, goethite $(\mathrm{FeO}(\mathrm{OH}), 62.9 \% \mathrm{Fe})$, limonite $\left(\mathrm{FeO}(\mathrm{OH}) \cdot \mathrm{n}\left(\mathrm{H}_{2} \mathrm{O}\right)\right.$ or siderite $\left(\mathrm{FeCO}_{3}, 48.2 \% \mathrm{Fe}\right)$. Iron ore is one of the most common minerals on the surface of the earth(Emerson et al., 2010). The importance of iron is strongly linked to its hardness, durability, strength and ability to form alloys with other metals. These properties have made iron special and suitable for different applications in various industrial processes. The economic and environmental gains arising from the use of alternative technologies in bio mining of iron calls for more work in the field of environmental biotechnology (Alafara et al.,2005). Current understanding of the mechanism of solubilisation is that it is primarily a chemical process, although attachment of microbes to the mineral can enhance dissolution.The major advantage of bioleaching over other methods of metal extraction is that special microorganisms act on mineral deposits, as a catalyst and speed up natural processes inside the ore. The bacteria use a chemical reaction called oxidation to turn metal sulphide or oxides crystals into sulphates/oxalates and pure metals (Straub and Skink, 2001). Bioleaching involves numerous ferrous iron and sulphur oxidizing bacteria. As a general principle, $\mathrm{Fe}^{3+}$ ions are used to oxidize the ore. This step is entirely independent of microbes. The role of the bacteria is further oxidation of the ore and the regeneration of the chemical oxidant $\mathrm{Fe}^{2+}$. For example, bacteria catalyze the breakdown of the mineral pyrite $\left(\mathrm{FeS}_{2}\right)$ by oxidizing the sulfur and metal (in this case ferrous ion, $\mathrm{Fe}^{2+}$ ) using oxygen. This yields soluble products that can be further purified and refined to yield the desired metal(Hallberg, 2010).All microbes whether prokaryotic or eukaryotic, employ metal species for structural functions and/or catalytic functions, e.g the alkali metals $\mathrm{Ca}$ and $\mathrm{Mg}$ serve structural as well as catalytic functions.

Molecular methods such as polymerase chain reaction (PCR) are useful analytical tools for evaluating the Mining microbial community's structure and function. PCR have become a common tool for detecion, identification and characterization of microbial communities (AppiaAymeet al.,1999). The isolated genes from bio mining organisms should be amenable to sequence homology alignment to find organisms with similar evolutionary genomes for a very efficient cloning experiment. DNA extraction procedures are important parts of the investigations. These procedures must provide DNA in sufficient quantity and purity for molecular analyses especially when large number of samples need to be analysed. The application of molecular biology techniques in microbial ecology allows for a more realistic assessment of microorganisms and their interactions in various environments (Bartels et al., 1989). Soil and ores from mining site are examples of a heterogeneous habitat where traditional techniques used for micro flora characterization have been improved by methods based on DNA/RNA analysis. However, the use of DNA-based techniques has one major limitation; DNA of sufficient quality and quantity is required. When DNA is extracted from a contaminated mining area, heavy metals may be significant inhibitors of the DNA amplification by Taqpolymerase (Valde et al., 2008). Conventional technologies involved in metal extraction from metallic ores are economically expensive in monetary terms and human labour and are also environmentally unfriendly. Many of the by-products of extraction by thermal and chemical means are toxic to man and his environment and constitute sizeable environmental pollutants in cities and industrial layouts (Alafara et al., 2005). On the search for more environmentally sound technologies for the mining industry, biological processes to extract metals from ores, pre- 
treating metallic ores or removing contaminants from metallic ores or industrial wastes and using molecular techniques to characterize microbial communities from mining sites have been developed for different metallic mineral resources. The aim of thispresent work was to determine the bioleaching capabilities of some pure and mixed consortium of three isolated bacterial species from Agbaja Mining site of Kogi state Nigeria and investigate the quality and quantity of their DNA with a view to finding their suitability for further molecular characterization.

\section{Materials and Methods}

All reagents and chemicals used in this study were of high analytical grade. Some of the equipment used include Intelligent Thermostatic Shake Cultivation Cabinet (incubator shaker) made in England, Vertical Heating Pressure Steam Sterilizer (autoclave), Colony Counter, General Laboratory Oven made in andLaboratory Incubator, Atomic Absorption Spectrophotometer, etc.

\section{Sample Collection}

Crushed iron ore samples were collected at different locations within Agbaja iron ore mining site from the upper layer where most of the microbial activity takes place and thus where most of the bacteria population is concentrated. Iron ore samples were collected using some clean dry and sterile polythene bag along with sterile geological fork. $50 \mathrm{~g}$ of the iron ore samples were placed in $100 \mathrm{ml}$ of distilled water to make iron ore suspensions and kept on an incubator shaker for 21 days at $160 \mathrm{rpm}$.

\section{Media Preparation and Isolation of bacteria (Okibe, 2004)}

The $\mathrm{pH}$ of the pre incubated solution above was adjusted between 2.0-5.0 using $0.1 \mathrm{ml}$ of concentrated sulphuric acid $\left(\mathrm{H}_{2} \mathrm{SO}_{4}\right)$. The conical flasks were then plugged with cotton wool and the suspension homogenized and incubated for another 7 days in the incubator shaker at $30^{\circ} \mathrm{C}$. A $9 \mathrm{~K}$ modified media was prepared containing the following: $\left(0.8 \%\right.$ Urea, $0.1 \% \mathrm{~K}_{2} \mathrm{HPO}_{4}, 0.025 \% \mathrm{MgSO}_{4} . \mathrm{H}_{2} \mathrm{O}, 0.03 \%$ $\mathrm{FeSO}_{4} .7 \mathrm{H}_{2} \mathrm{O}, 0.02 \%$ yeast extract and $10 \%$ glucose) and nutrient agar in $250 \mathrm{ml}$ of solution at $37^{\circ} \mathrm{C}$ ( $\mathrm{pH}$ 2.0) and incubated for 24-72 hours. The media was autoclaved at a temperature of $121^{\circ} \mathrm{C}$ for 15 minutes, allowed to cool at room temperature and $9 \mathrm{ml}$ of the pre-incubated sample (in the incubator shaker) was pipetted into sterilized petri dishes. The cooled media was then dispensed into the petri dishes and allowed to gel. They were then incubated for 24-72 hours at various temperature to determine the growth rate of bacteria at different hours per temperature.

\section{Examinations of Pure Bacteria Cultures}

Portions of the cultures above were inoculated on nutrient agar by streaking and were incubated at $37^{\circ} \mathrm{C}$ for 24 hours in order to identify the pure cultures tentatively by matching with the Bergey's manual. Gram staining and various biochemical tests were then carried out as outlined below.

\section{Morphology}

The colony morphology was viewed with the aid of a colony counter. Morphological characteristics such as colony, edges, surface, and elevation were observed.

\section{Gram Staining}

A drop of distilled water was placed on a clean glass slide and a loop of the bacterial isolate was smeared on the water which was then allowed to dry. It was then passed through a flame twice in order to heat fix it. One to two drops of crystal violet was added and left for 60seconds before washing it with distilled water. Grams iodine was added and washed away with distilled water after 1 minute. It was then flooded with alcohol (ethanol) and washed with distilled water after 30seconds and then adding safranin which was also washed with distilled water after 30 seconds. The glass slide was left to dry and examined under the microscope. 


\section{Catalase Test}

This is a test to ascertain the ability to produce Catalase that reduces hydrogen peroxide to water and oxygen. On a clean glass slide, a smear of the organisms was made in a drop of normal saline with a flame sterilized wire loop. Thereafter, a drop of hydrogen peroxide was placed on the smeared organism. If effervescence occurs, it is confirmatory positive test for catalase production, but if it does not occur it is negative test for catalase production.

\section{Oxidase Test}

A piece of filter paper was soaked in oxidase reagent and the paper placed in a clean sterilized petridish. With an inoculating loop, a smear of the organism was made in a drop of normal saline on the filter paper and left for 30 seconds. Purple colour shows a positive test, colourless is negative.

\section{Growth in $\mathrm{NaCl}$}

This is a test to ascertain the ability of the isolate to tolerate high salt concentration. About $(7 \mathrm{~g})$ of $\mathrm{NaCl}$ was dissolved in $100 \mathrm{ml}(7 \%$ solution) of Nutrient agar and was poured into slant bottles. The isolate was inoculated into the medium; incubation was for 24 hours at room temperature.

\section{Bioleaching studies (Welch et al.,2002)}

Four grams of the iron ore sample were weighed and transferred into six sterilized McCartney bottles.10ml of distilled water was added to the six bottles and inoculated with the bacteria in this order: single cultures of Acidithiobacillus, Leptospirillum, and Pseudomonas specie, and mixed cultures of Acidithiobacillus + Leptospirillum species, Acidithiobacillus + Pseudomonas species, Leptospirillum specie + Pseudomonas species, and Acidithiobacillus + Leptospirullum specie + Pseudomonas species. They were incubated at $37^{\circ} \mathrm{C}$ for 6 days, while the seventh bottle without the inoculum serves as the control. At the end of each day, the samples were filtered, washed with $2 \%$ Sodium dodecyl sulphate (SDS) and the residue dried. $3 \mathrm{ml}$ from each inoculated samples were taken after every 24 hours to determine the iron content through simple titration in order to examine the degree of bioleaching by the bacteria per time.

\section{Determination of Iron ( $\mathrm{Fe}$ ) content using $\mathrm{K}_{2} \mathrm{Cr}_{2} \mathrm{O}_{7}$ method (titration) (AOAC, 1990)}

$3 \mathrm{ml}$ from each inoculated sample above was introduced into a conical flask containing $100 \mathrm{ml}$ of distilled water. The $\mathrm{pH}$ of the solution was adjusted to 2.0 using $1 \mathrm{ml}$ concentrated $\mathrm{H}_{2} \mathrm{SO}_{4}$. Thereafter the suspension was homogenized and the sample filtered to obtain the filtrate for analysis. $10 \mathrm{ml}$ of the solution (filtrate) was transferred into a conical flask with a $10 \mathrm{ml}$ pipette. $25 \mathrm{ml}$ of $1 \mathrm{M} \mathrm{H}_{2} \mathrm{SO}_{4}, 10 \mathrm{ml}$ of $1 \%$ Phosphoric acid solution, and 8 drops of diphenylamine indicator was added. The flask was swirled gently to mix the content. The burette was filled with $0.05 \mathrm{M} \mathrm{K}_{2} \mathrm{Cr}_{2} \mathrm{O}_{7}$. The initial volume from the calibrated scale on the burette was read. The iron solution in the conical flask was titrated. The intense purple colour produced by the first drop of excess $\mathrm{K}_{2} \mathrm{Cr}_{2} \mathrm{O}_{7}$ signal the end point. The final volume reading from the calibration scale on the burette was obtained. This was repeated twice and the average titre of duplicates determined. The percentage mass of the iron was then calculated.

\section{DNA extraction}

$1 \mathrm{ml}$ of the suspension from the conical flask was inoculated into each petri-dish and the media dispensed into the petri-dishes by pour plate method and allowed to gel and incubated at $37^{\circ} \mathrm{C}$ for 48 hours. Bacteria that grew were sub-cultured into plates containing nutrient agar by streaking in order to obtain pure culture and were incubated at $37^{\circ} \mathrm{c}$ for 24 hours after which pure colonies were subcultured and DNA extraction was carried out. 

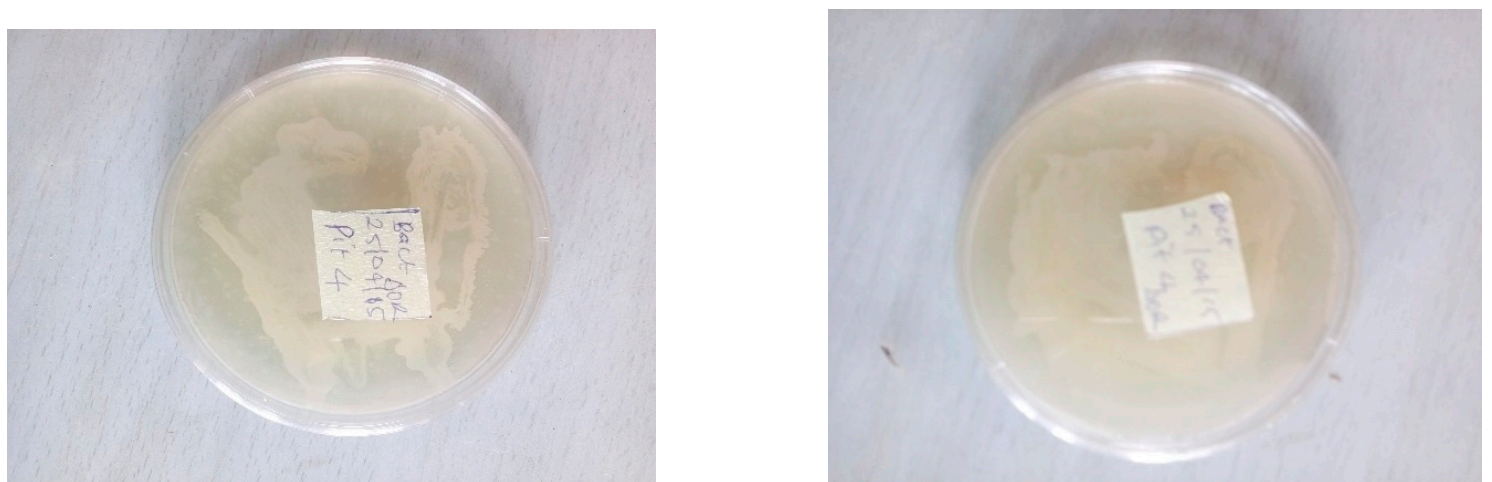

Plate 1\&2: Sub-cultured bacteria from Agbaja iron ore mining site

\section{DNA Isolation Using Zymo Research Fungal/Bacterial DNA Mini Prep Kit}

Genomic DNA extraction was carried out using the Zymo Research Fungal/Bacterial DNA $\mathrm{Kit}^{\mathrm{TM}}$ (Cat. \# 6001) according to the manufacturer's instructions. 100mg of the cell isolate was scooped under the laminar flow hood, suspended in $750 \mu 1$ lysis buffer and lysed. It was then vortexed for about 5 minutes and transferred to the centrifuge to spin at 12,000 rpm for about 3 minutes. The supernatant was transferred into the zymo-spin ${ }^{\mathrm{TM}}$ filter; it was then spinned at $10,000 \mathrm{rpm}$ forabout 2 minutes. $1,200 \mu \mathrm{l}$ of Bacterial DNA binding buffer was added to the filtrate and transferred to zymo spin IIC column and spinned at 12,000rpm for 2 minutes. The above steps were repeated and the filtrate discarded.Then, DNA pre-wash buffer was added to column and centrifuged at 12,000rpm for 2 minutes. The column contents were transferred into clean $1.5 \mathrm{ml}$ micro tube and $20-100 \mu 1$ of DNA elution was added to concentrate and thereafter spinned at 12,000rpm for about 1 minute to elute the DNA. Finally, electrophoresis was carried out on the DNA sample.

\section{Preparation of Gel for electrophoresis using Ethidium Bromide in 1\% agarose}

$1 \mathrm{~g}$ of Agarose was dissolved in $100 \mathrm{ml}$ distilled water and placed in the microwave to heat for 2 minutes and then cooled under running water. Ethidium bromide was added to the cooled gel and subsequently poured into the electrophoresis tank with the electrophoresis combs already set in the tank. This was then immersed in Tris-borate-EDTA (TBE) buffer. $5 \mu$ l of extracted DNA $+5 \mu$ l of loading dye-bromophenol blue (Fermenters) were dispensed into the wells. Standard DNA ladder (Fermentas $1000 \mathrm{bp}$ ) was loaded into the first and last wells. Initial denaturation step was carried out at $95^{\circ} \mathrm{C}$ for 5 mins. Cycle Denaturing step was undertaken at $94^{\circ} \mathrm{C}$ for $2 \mathrm{~min}$. Annealing step was also done at $52^{\circ} \mathrm{C}$ for $1 \mathrm{~min}$, and the Elongation step was taken at $72^{\circ} \mathrm{C}$ for $2 \mathrm{~min}$.Electrophoresis was then run at 120 volts for $40 \mathrm{mins}$. The gel picture was captured using the gel documentation system (Alpha mager ${ }^{\mathrm{TM}}$ ). DNA quality was further confirmed using the UV spectrophotometer.

\section{Results and Discussion}

\section{Growth Rate of bacteria.}

The growth rate of bacteria present in iron ore sample are shown in Figures 1-3. A.ferroxidans had a peak growth rate of $83 \%$ at 48 hours $\left(45^{\circ} \mathrm{C}\right)$, and least growth rate of $0 \%$ at 24 hours. Leptospirillum specie had a peak growth rate of $100 \%$ at 48 hours and $\left(45^{\circ} \mathrm{C}\right)$ also. While about $95 \%$ growth was recorded for pseudomonas at the same condition. 

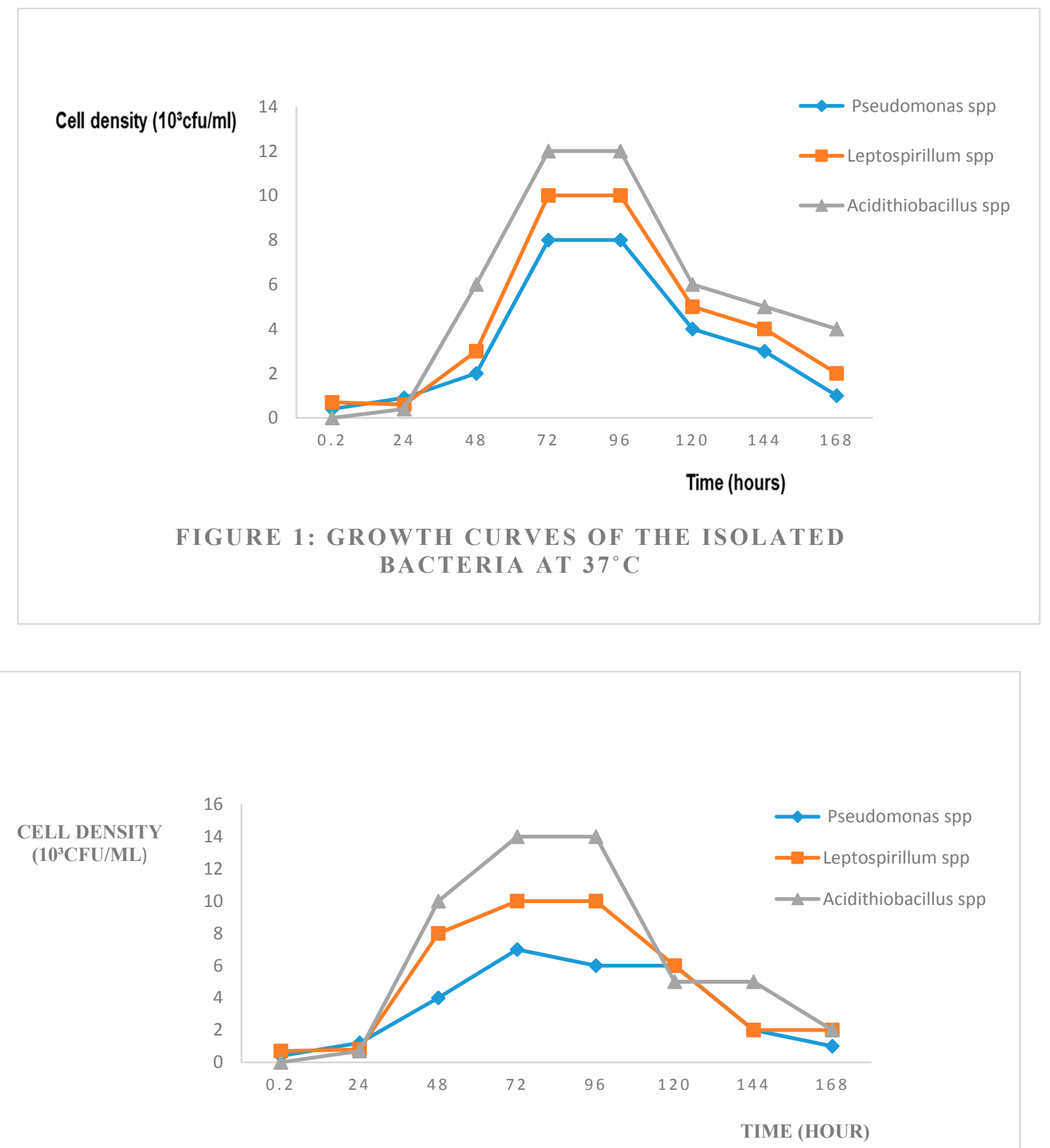

FIGURE 2: GROWTH CURVES OF THE ISOLATED BACTERIA AT $45^{\circ} \mathrm{C}$ 


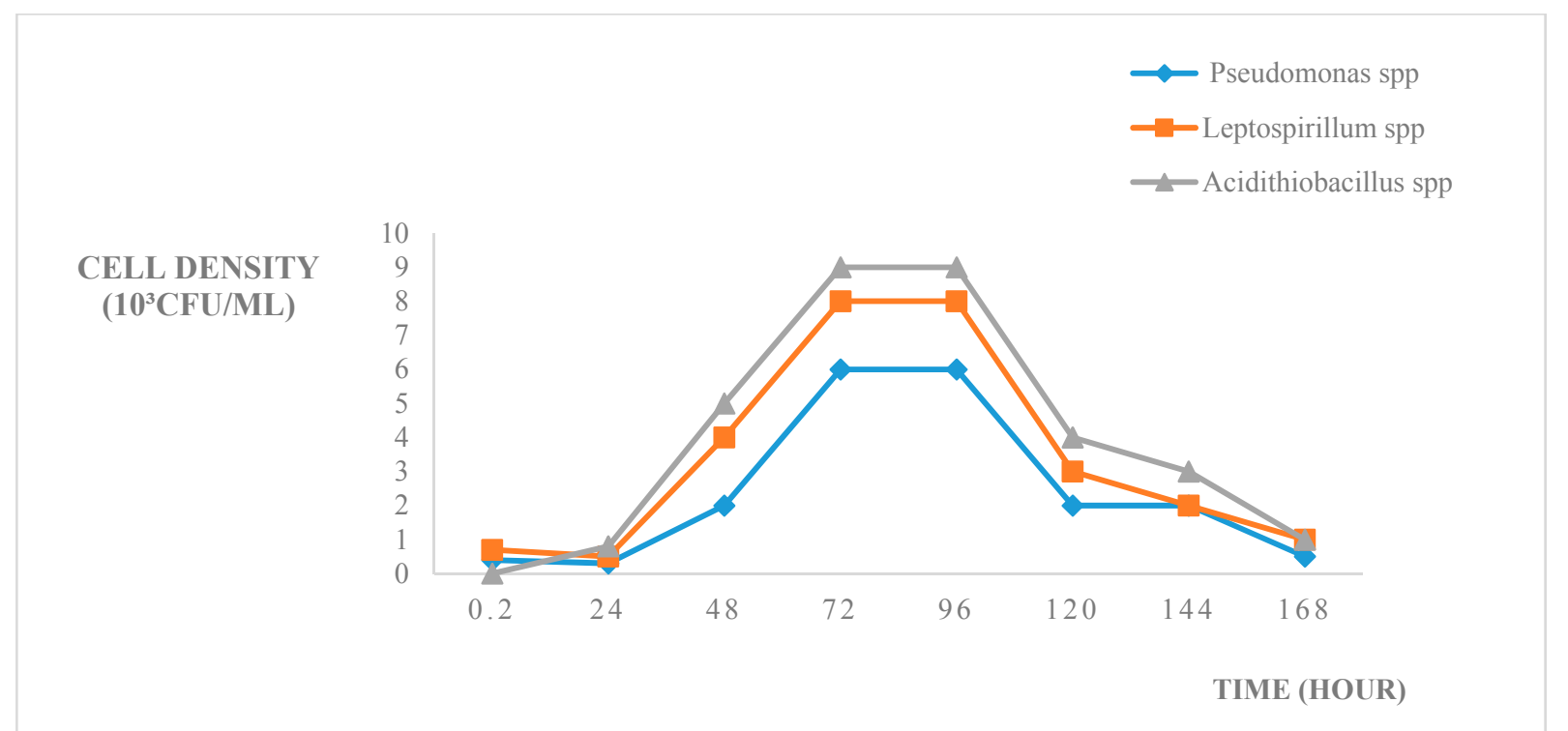

Figure 3: Growth curves of the isolated bacteria at $25^{\circ} \mathrm{C}$

Table 1: Identification and Characterization of Isolates

\begin{tabular}{|c|c|c|c|c|c|c|c|c|c|c|c|c|c|c|c|c|}
\hline $\begin{array}{l}\tilde{0} \\
\stackrel{0}{\pi} \\
0 \\
0 \\
0\end{array}$ & 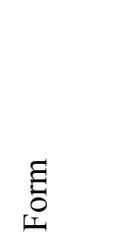 & $\frac{3}{0}$ & 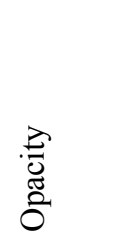 & $\frac{\mathscr{D}}{0}$ & 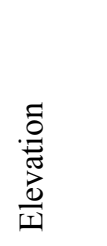 & 竞 $\frac{\frac{0}{0}}{\frac{0}{2}}$ & 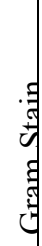 & 芯 & 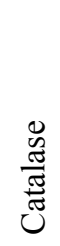 & $\bar{Z}$ & 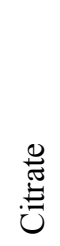 & $\begin{array}{l}\hat{y} \\
\text { : } \\
\text { d }\end{array}$ & $\begin{array}{l}0 \\
\mathscr{D} \\
0 \\
0 \\
0\end{array}$ & 导 & 总 & 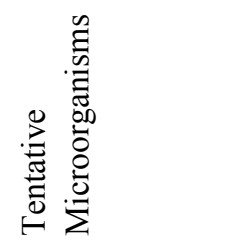 \\
\hline 1 & Circular & White & Opaque & Entire & Flat & Rod & - & - & + & - & + & A & A & A & + & $\begin{array}{l}\text { Acidithiobacillus } \\
\text { spp }\end{array}$ \\
\hline 2 & Circular & Cream & Opaque & Entire & Flat & Rod & - & - & - & - & + & + & + & A & - & $\begin{array}{l}\text { Leptospirillum } \\
\text { spp }\end{array}$ \\
\hline 3 & Irregular & White & Opaque & Lobate & Raised & Rod & + & + & + & - & + & + & A & A & + & $\begin{array}{l}\text { Pseudomonas } \\
\text { spp }\end{array}$ \\
\hline
\end{tabular}




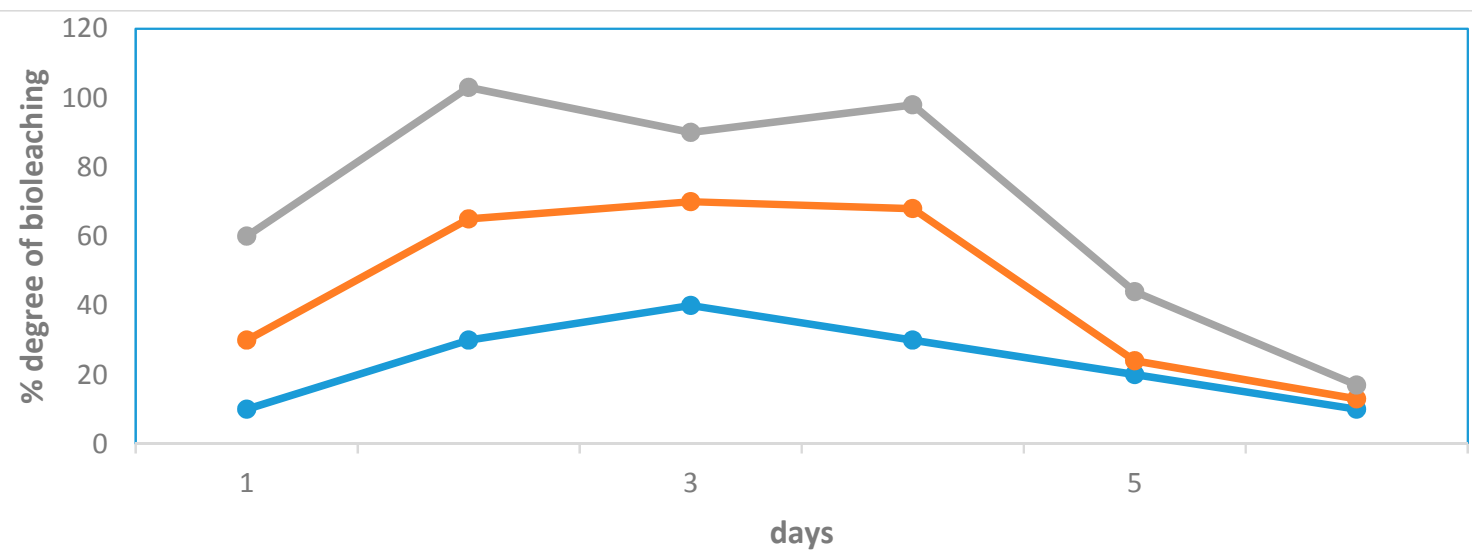

Figure 4: Degree of Bioleaching per day for pure cultures of Acidithiobacillus spp, Leptospirrillum, and Pseudomonas spp
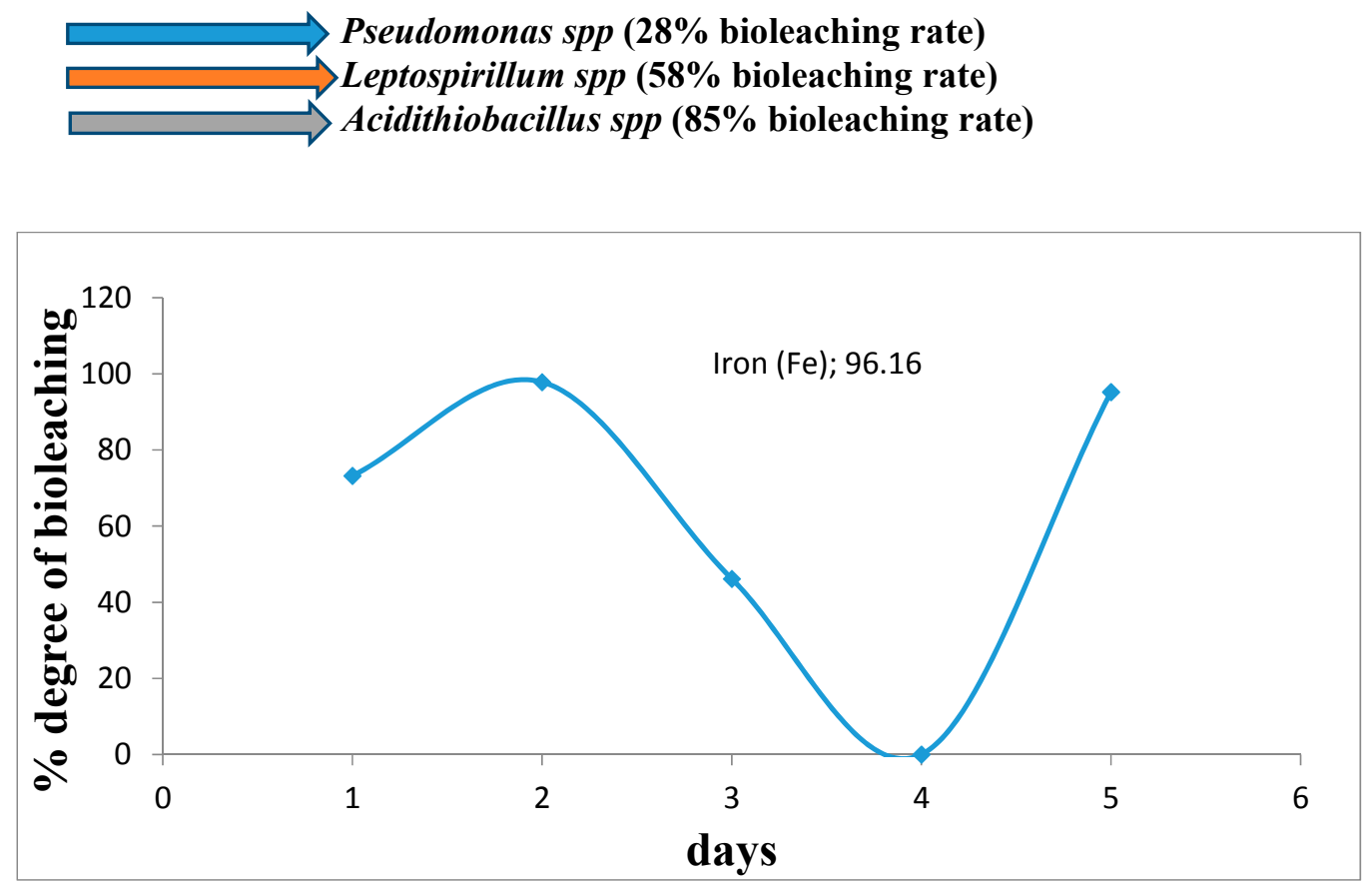

Fig 5: degreeof bioleaching per day for Acidithiobacillus species + Leptospirillum species 


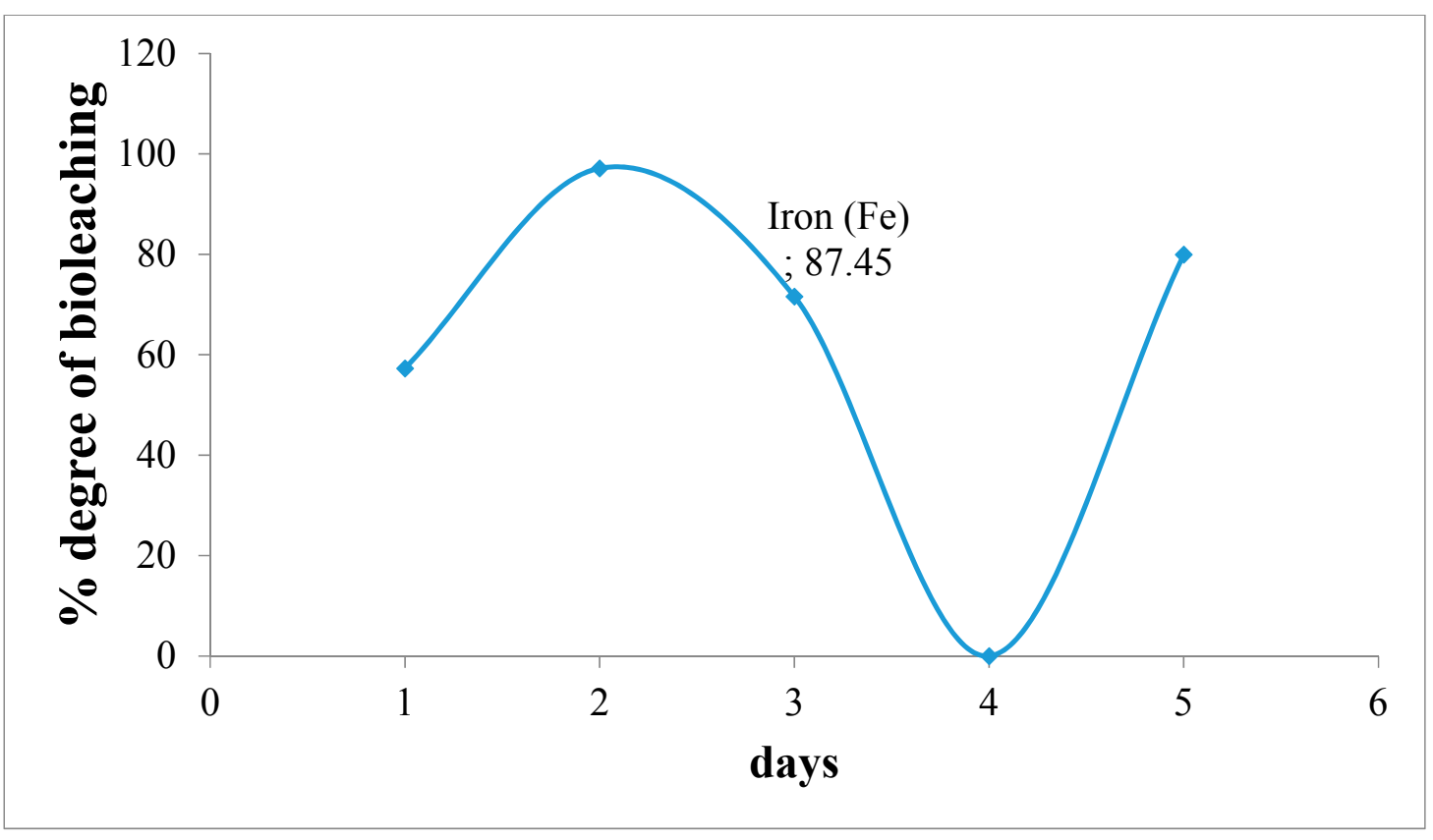

Fig 6: degree of bioleaching per day for Acithiobacillus species + Pseudomonas Species

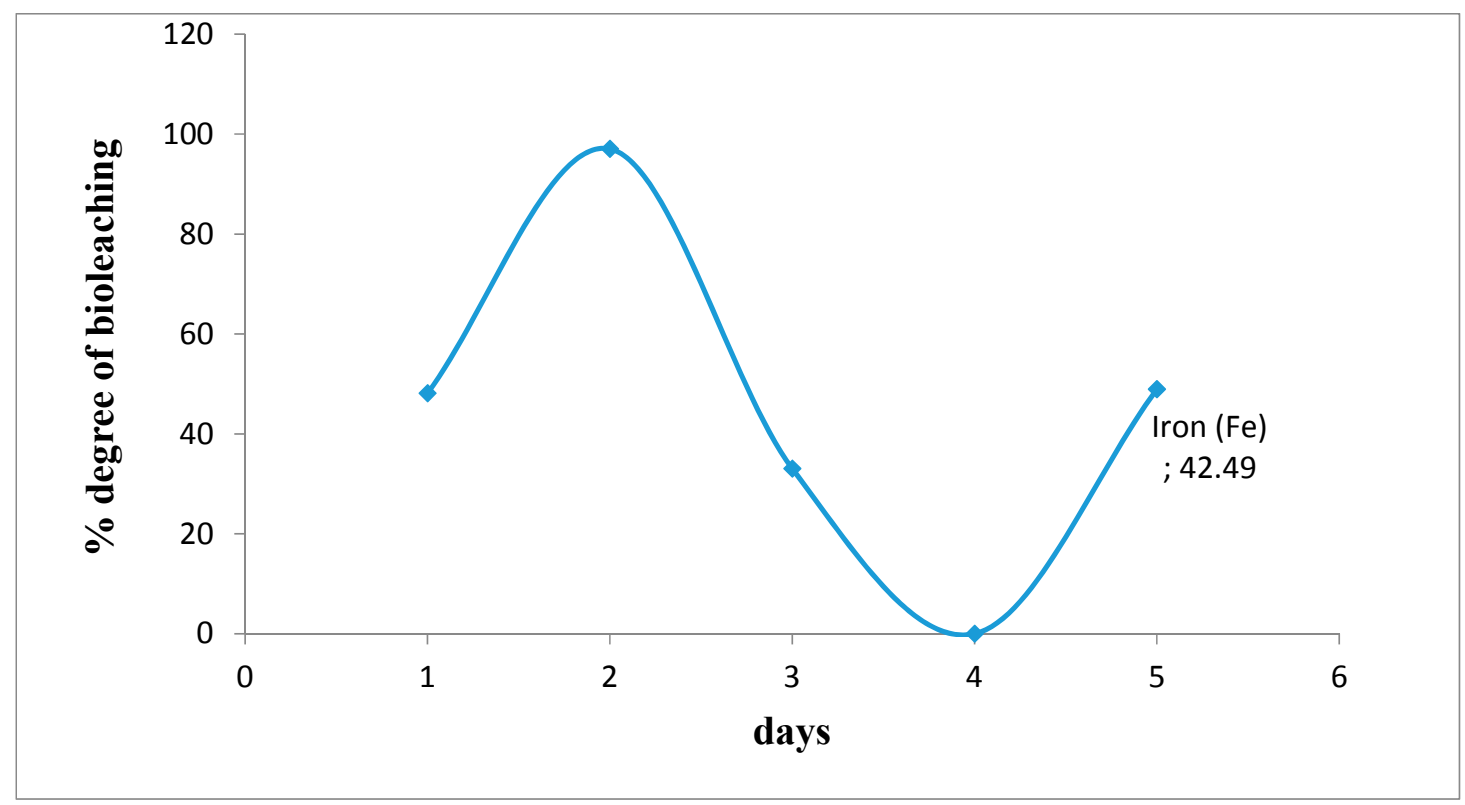

Fig 6: degree of bioleaching per day for Leptospirillum specie + Pseudomonas Specie 


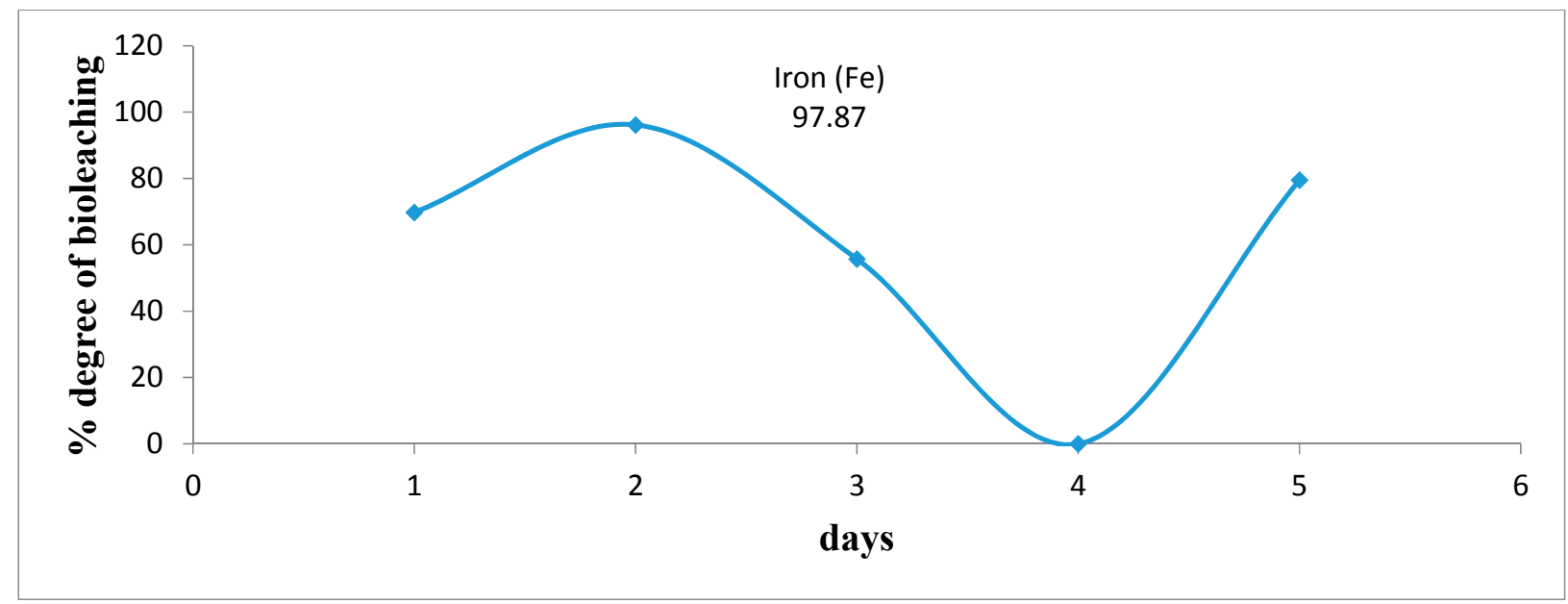

Fig 7: degree of bioleaching per day for the mixed microbial consortium

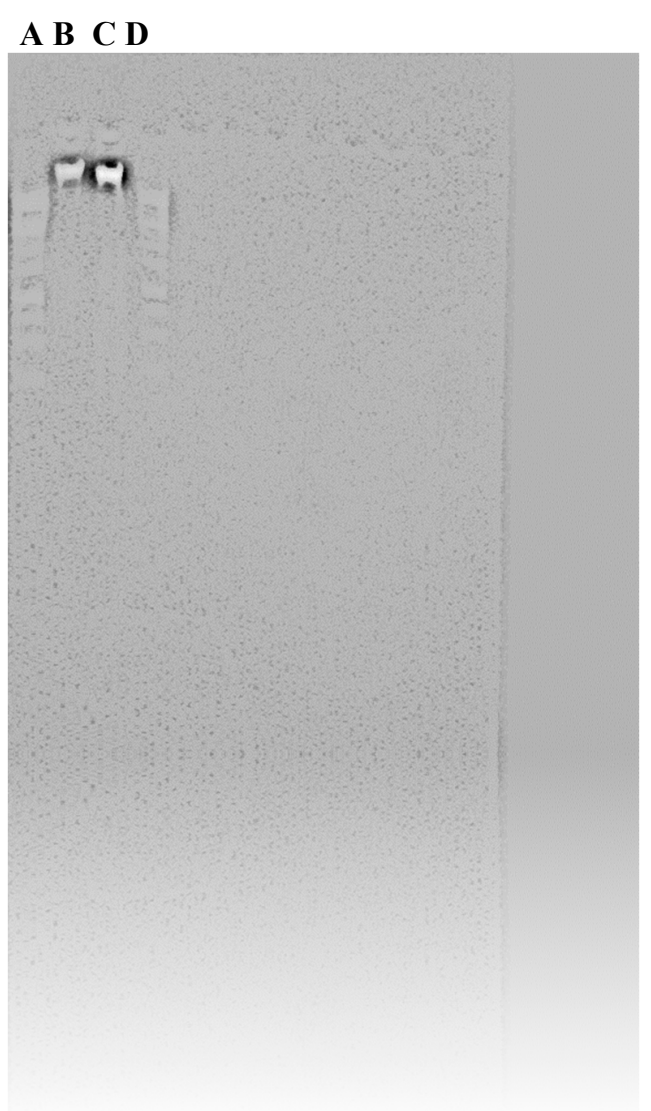

Figure 8: Gel electrophoresis micrograph of genomic DNA from Acidithiobacillus and Leptospirillum species; (Pseudomonas didn't yield any significant amount of DNA)
A- Standard marker Lane
B- B-Lane 2 Corresponding to A.Ferroxidans genomic DNA at 1.5kbp
C- C-Lane 3 corresponding to Leptospirillum species genomic DNA at 1.3kbp
D- D-Standard marker Lane 


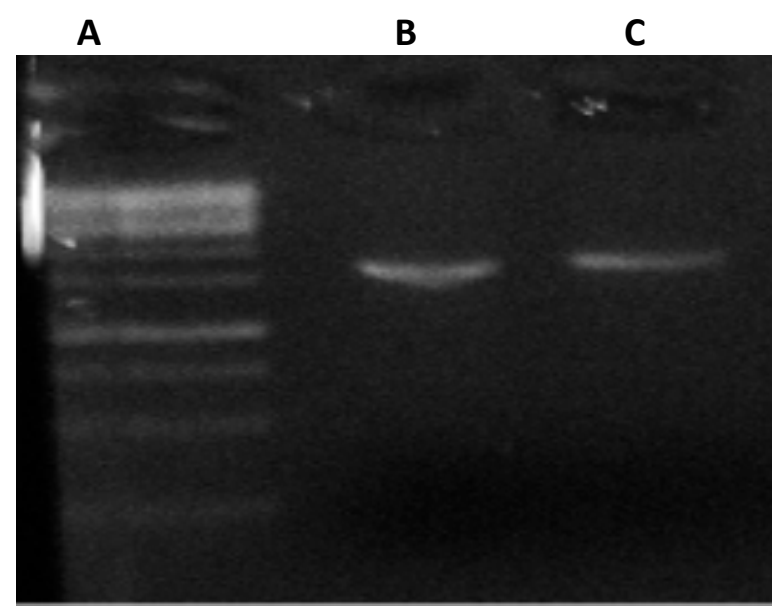

Figure 9: Gel electrophoresis micrograph of PCR product from extracted DNA above. Using the Fermentas $1 \mathrm{~Kb}$ reference ladder, the PCR product corresponds to $1.5 \mathrm{kbp}$ and $1.6 \mathrm{kbp}$
A- Standard marker Lane
B- Lane 2 Corresponding to A.Ferroxidans amplified DNA
C- Lane 3 corresponding to Leptospirallum species amplified DNA

\section{Discussion}

The entire degree of bioleaching from day 1 to 5 (figures 4-7), suggest that bioleaching increases with time and also a function of the growth pattern of the bioleaching organism. This is in conformity with Chime et al., (2011) who reported that iron ore bioleaching follows the normal bacteria growth kinetics. Metals and their compound interact with microbes in various ways depending on the type of metal, organism and environment, and cellular composition of the microbes. This might have accounted for the fluctuation in the rate of bioleaching of the diverse mixed consortium observed in this work. microbes are intimately associated with biogeochemical cycling of metals and elements as a result of immobilization depending on the mechanism involved and the microflora of organism(Emersonet al.,2010 ).Bacteria resistance mechanisms generally involve efflux or enzymatic detoxification which can lead to the release of some metallic ion from the cell, as a result of this mechanism, microbes (bacteria) may synthesize varieties of metals binding peptide and proteins which regulate metal ion homeostasis and can also affect toxic responses. The variations in the bioleaching rates seen in both pure cultures and mixed consortia could also be as a result of some microbial process like energy generation, nutrient acquisition, cell adhesion and biofilm formation (Okibe 2004). In addition, potentially toxic metals released from minerals as a result of physiochemical and biological process may also affect microbial community diversity. The bioleaching of $\mathrm{Fe}$ for different combinationsis shown in Fig4-7. The results indicated that more than 90\% of Fe was solubilized after 2 days of bioleaching when mixed cultures are used and reached maximum removal efficiency of approximately $100 \%$ when the whole organisms were combined together.No significant difference in Fe removal was noted between mixed cultures as opposed to the single cultures with lower bioleaching rate. The leaching of $\mathrm{Fe}$ was related to the $\mathrm{pH}$, temperature, and composition of the bioleaching medium as indicated by the concomitant sharp release of $\mathrm{Fe}$ together with the increase in incubation time and temperature in the initial period of bioleaching 
(Nwoye, 2007). The control experiment could only achieve $18 \%$ of Fe bioleaching ( results gotten from some previous pilot studies but not shown here). At the end of the bioleaching period of 5 days, Fe content was observed to be picking up gradually again. This explains the reason why it took less time for the mixed consortia systems to reach maximum leaching efficiency as compared to the pure cultures system. It also means that the higher solubilisation yield of Fe in the mixed system may not only depend on the decrease in some physico chemical parameters but also other factors such as activities of other indigenous microorganisms in the ores and nature of the inoculated bacteria (Nwoye, 2012).

After identification of the organisms (Table 1)In this work, a simple but rapid method of DNA isolation for the Agbaja iron ore samples was achieved (Figures 8-9). Current available methods of DNA extraction have been found to be costly and time consuming and lead to substantial loss of quality DNA for molecular analysis. This DNA extraction method was also found to have the following advantages: Good yields of high quality genomic DNA, Circumvention of the use of liquid nitrogen for crushing of the bacterial biomass, Reduction in the extraction steps, Minimal requirement of chemicals and equipment needed for lysis and extractionandUse of toxic and potentially hazardous substances eliminated.High molecular weight DNA $(>1.0 \mathrm{~kb}$, figure 8$)$ resulted from the use of this method. The ratio of the absorbance at 260 and 280 was found to be 1.6 indicating a good purity with very little smear on the DNA. The PCR technique further ascertain the quality of the extracted DNA (figure 9). The isolated DNA produced good banding patterns for A. ferroxidans and Leptospirillum spp indicating its good quality. The entire DNA extraction kit also worked well in releasing large quantities of DNA from the bacteria culture used. However no significant DNA was extracted from the Pseudomonas species probably due to extraction protocol or the fact that pseudomonas species are very rare in environments where iron is predominant (Rodden and Urratia, 1999). The DNA isolated from the bacteria culture was well resolved on $1.5 \%$ agrose gel. This shows that the isolated DNA is free of polysaccharides and polyphenols which are known to inhibit taq DNA polymerase and restriction endonucleases (Valdeet al., 2008). Pure DNA eluted from the agarose gel ensures reliable DNA amplification by PCR. In conclusion, this work has shown that the extraction method generated DNA that can be used in various molecular analysis while the results of PCR analysis further confirms the quality and quantity of the isolated DNA that are suitable for further genetic analysis. Results of allthe analysis carried out (fig 1- 7) shows that bioleaching efficiencies of the single and mixed organisms from Agbaja iron ore samples could have been enhanced by proteolysis, complexation by extracted metals, $\mathrm{Fe}^{3+}$ binding siderophores, and general redox reactions. It has been shown that microbes and their extracellular products can influence the mobility of metals like $\mathrm{Cu}$ and $\mathrm{Fe}$ from mining site or dump site even under low nutrient system.

\section{Reference}

Alafara, A.B., F.A.O. Adekola and A.O. Folashade, (2005). Quantitative leaching of a Nigerian ore in hydrochloric acid. Journal of Applied science and Environment, 9(3): 15-20.

Appia-Ayme, C., Guiliani, N., Ratouchniak, J. \& Bonnefoy, V. (1999). Characterization of an operon encoding two c-type cytochromes, an aa3-type cytochrome oxidase, and rusticyanin in Thiobacillus ferrooxidans ATCC 33020. Appl Environ Microbiol 65, 47814787 
Association of Official Chemist. (AOAC) (1990). Official method of Analysis. Kluwer Academic Press, New York

Bartels, C. C.; G. Chatzitheodoru, M. Rodriguez- Levik; Tributsch H. (1989) Novel technique for investigation and quantification of bacterial leaching by thiobacillus ferroxidans

Chime, T.O, Onukwuli, O.D and Menkiti, M.C, (2011) Biodephosphorization of Iron ore using Acidothiobacillus ferroxidans. New York Science Journal 4 (1) 1-6

Emerson, D., Fleming, E. J. \& McBeth, J. M. (2010). Iron-oxidizing bacteria: an environmental and genomic perspective. Annu Rev Microbiol 64, 561-583.

Hallberg, K. B. (2010). New perspectives in acid mine drainage Microbiology. Hydrometallurgy 104, 448-453.

Nwoye, C. I. (2007) Gaseous state Desulphurization of Agbaja Iron Ore Concentrate. Journal of Engineering and Applied Sciences, Vol. 3, pp 72- 75.

Nwoye, C. I. (2012). Upgrading of Agbaja Iron Ore Concentrate using pyrological method. JMME, Vol. 3, No.1, pp. 14-16.

Okibe N, Johnson DB (2004) : Biooxidation of pyrite by defined mixed cultures of moderately thermophilic acidophiles in $\mathrm{pH}$-controlled bioreactors: significance of microbial interactions. Biotech Bioeng, 87:574-583.

Roden, E. E. \& Urrutia, M. M. (1999). Ferrous iron removal promotesmicrobial reduction of crystalline iron(III) oxides. Environ Sci Technol33, 1847-1853.

Straub, K. L., Benz, M. \& Schink, B. (2001). Iron metabolism in anoxic environments at near neutral pH. FEMS Microbiol Ecol 34, 181-186.

Valde' s, J., Pedroso, I., Quatrini, R., Dodson, R. J., Tettelin, H., Blake, R., II, Eisen, J. A. \& Holmes, D. S. (2008). Acidithiobacillus ferrooxidans metabolism: from genome sequence to industrial applications. BMC Genomics 9, 597.

Welch, S.A., Taunton, A.E., Banfield, J.F. (2002). Effect of microorganism and microbial metabolites on apatite dissolution geomicrobiology journey, 19: 343-367. 